\title{
Gefitinib provides similar effectiveness and improved safety than erlotinib for east Asian populations with advanced non-small cell lung cancer: a meta-analysis
}

\author{
Wenxiong Zhang, Yiping Wei $\mathbb{D}^{*}$, Dongliang Yu, Jianjun Xu and Jinhua Peng
}

\begin{abstract}
Background: The first-generation epidermal growth factor receptor tyrosine kinase inhibitors gefitinib and erlotinib have both been proven effective for treating advanced non-small cell lung cancer (NSCLC), especially in East Asian patients. We conducted this meta-analysis to compare their efficacy and safety in treating advanced NSCLC in this population.

Methods: We systematically searched PubMed, ScienceDirect, The Cochrane Library, Scopus, Ovid MEDLINE, Embase, Web of Science, and Google Scholar for the relevant studies. Overall survival (OS), progression-free survival (PFS), objective response rate (ORR), disease control rate (DCR), and adverse effects (AEs) were analyzed as primary endpoints.

Results: We identified 5829 articles, among which 31 were included in the final analysis. Both gefitinib and erlotinib were effective for treating advanced NSCLC, with comparable PFS (95\% confidence interval [CI]: 0.97-1.10, $p=0.26$ ), OS (95\% Cl: $0.89-1.21, p=0.61$ ), ORR (95\% Cl: $1.00-1.18, p=0.06$ ), and DCR (95\% Cl: 0.93-1.05, $p=0.68)$. Erlotinib induced a significantly higher rate of dose reduction ( $95 \% \mathrm{Cl}: 0.13-0.65, p=0.002)$ and grade $3-5 \mathrm{AEs}(95 \% \mathrm{Cl}$ : $0.27-0.71, p=0.0008$ ). In subgroup analysis of AEs, the erlotinib group had a significantly higher rate and severity of skin rash, nausea/vomiting, diarrhea, fatigue and stomatitis.

Conclusions: With equal anti-tumor efficacy and fewer AEs compared with erlotinib, gefitinib is more suitable for treating advanced NSCLC in East Asian patients. Further large-scale, well-designed randomized controlled trials are warranted to confirm our findings.
\end{abstract}

Keywords: Gefitinib, Erlotinib, Non-small cell lung cancer, East Asian populations, Targeted therapy, Meta-analysis

\section{Background}

In Asia, lung cancer is the most common cancer in men (age-standardized rate $[$ ASR; per 100,000] 35.2 ) and the third most common cancer in women (ASR $=12.7$ ). The number of patients with lung cancer has increased rapidly by the year $[1,2]$. The discovery and development of therapeutics targeting epidermal growth factor receptor (EGFR), namely tyrosine kinase inhibitors (TKIs), in the past decade was an important clinical advance in non-small cell lung cancer (NSCLC) treatment

\footnotetext{
* Correspondence: weiyiping2015@163.com

Department of thoracic surgery, The second affiliated hospital of Nanchang University, 1 Min De Road, Nanchang 330006, China
}

$[3,4]$. Recommended by clinical guidelines, both gefitinib (Iressa) and erlotinib (Tarceva) are now widely accepted as standard-of-care therapy for patients with NSCLC whose tumors harbor activating EGFR mutations, especially patients with certain clinical characteristics (Asian descent, female gender, never-smoker, adenocarcinoma) [5-8]. The EGFR TKIs gefitinib and erlotinib both achieve a higher response rate for treating NSCLC in East Asian countries than in the Western countries [9]. However, which EGFR TKI can achieve better efficacy is controversial. In a phase III randomized controlled trial (RCT), Urata reported a higher incidence of grade 3-4 skin rash but less alanine aminotransferase/aspartate

(c) The Author(s). 2018 Open Access This article is distributed under the terms of the Creative Commons Attribution 4.0 International License (http://creativecommons.org/licenses/by/4.0/) which permits unrestricted use, distribution, and reproduction in any medium, provided you give appropriate credit to the original author(s) and the source, provide a link to the Creative Commons license, and indicate if changes were made. The Creative Commons Public Domain Dedication waiver (http://creativecommons.org/publicdomain/zero/1.0/) applies to the data made available in this article, unless otherwise stated. 
aminotransferase elevation in the erlotinib arm. Progression-free survival (PFS), overall survival (OS), and objective response rate (ORR) were similar between the two groups [10]. In another phase III RCT, Yang reported that gefitinib and erlotinib had similar efficacy (PFS, OS, ORR) in NSCLC, with similar toxicities [11]. Some studies have shown that gefitinib has better anti-tumor efficacy or less toxicity for NSCLC [12, 13]. However, other studies have reported opposite results and have suggested that erlotinib is more effective $[14,15]$.

To resolve this controversy, we conducted a meta-analysis of related studies to compare the anti-tumor efficacy and adverse effects (AEs) of gefitinib and erlotinib for treating East Asian populations with NSCLC.

\section{Methods}

We conducted this meta-analysis according to PRISMA (Preferred Reporting Items for Systematic Review and Meta-Analysis) guidelines.

\section{Search strategy}

The relevant literature was retrieved using the following electronic databases: (1) PubMed; (2) ScienceDirect; (3) The Cochrane Library; (4) Scopus; (5) Web of Science; (6) Embase; (7) Ovid MEDLINE; and (8) Google Scholar. The last search was on February 14, 2018. The following terms were used: "gefitinib", "erlotinib", and "Lung cancer". The complete search we used for PubMed was: (gefitinib [MeSH Terms] OR gefitinib [Text Word] OR IRESSA [Text Word] OR ZDl839 [Text Word]) AND (erlotinib [MeSH Terms] OR erlotinib [Text Word] OR Tarceva [Text Word] OR OSI-774 [Text Word]) AND (lung cancer [MeSH Terms] OR lung cancer [Text Word] OR lung carcinoma [Text Word] OR lung neoplasm [Text Word] OR NSCLC [Text Word]). The references of retrieved articles were also searched for further eligible articles. No language restriction was imposed.

\section{Selection criteria}

Articles that met the following criteria were included: (1) East Asian population with histologically or cytologically confirmed NSCLC based on the Eastern Cooperative Oncology Group; (2) compared gefitinib versus erlotinib; (3) outcomes were PFS, OS, ORR, disease control rate (DCR), and AEs. We excluded reviews without original data, meta-analyses, animal experiments, abstracts only, and studies with duplicated data.

\section{Data extraction}

Two investigators extracted the following data independently: first author, publication year, country, number of participants, participant characteristics (age, sex, stage of cancer, pathological type, line of treatment), anti-tumor efficacy indices (PFS, OS, ORR, DCR), and number of AEs (total AEs, grade 3-5 AEs). A third investigator resolved disagreements on all terms.

\section{Quality assessment}

The quality of RCTs was assessed using the 5-point Jadad scale, which contains questions on three main items: randomization, masking, and accountability of all patients. High-quality studies score $\geq 3$ points [16].

The quality of cohort studies was assessed using the Newcastle-Ottawa Scale (NOS, 9 points), which also contains questions on three main items: selection, comparability, and exposure. High-quality studies score 8-9 points; medium-quality studies score $6-7$ points [17].

\section{Statistical analysis}

The meta-analysis was conducted using Review Manager (version 5.3, The Nordic Cochrane Centre) and STATA (version 12.0, Stata Corp). Hazard ratios (HR) with 95\% confidence intervals $(\mathrm{CI})$ were used to analyze the PFS and $\mathrm{OS}$ (HR $>1$ favors the erlotinib group; $\mathrm{HR}<1$ favors the gefitinib group). The HR data were extracted directly from some studies or from Kaplan-Meier curves according to Tierney et al. [18] from other studies. Pooled risk ratios (RR) with 95\% CIs were used to analyze the ORR, $\mathrm{DCR}$, and AEs (RR $>1$ favors the gefitinib group; $R R<1$ favors the erlotinib group). Subgroup analysis of PFS, OS, and ORR was conducted to determine whether the results would change according to EGFR mutation status, ethnicity, line of treatment, histology, tumor stage, and study design. Heterogeneity was evaluated using the $\chi^{2}$ test and $I^{2}$ statistic. If $I^{2}>50 \%$ or $p<0.1$ for the $\chi^{2}$ test, reflecting significant heterogeneity, the random-effects model was used; otherwise, the fixed-effects model was used. Publication bias was explored using Begg's rank correlation and Egger's linear regression tests. $P<0.05$ indicated statistical significance.

\section{Results}

Search results and study quality assessment

We initially identified 5829 potentially eligible studies. After screening, 31 studies involving 8054 patients (gefitinib group, 4907 patients; erlotinib group, 3147 patients) were included for the final analysis (Fig. 1) [10-15, 19-43]. Of the 31 studies, three were RCTs and 28 were retrospective studies. Twenty-two studies were of high quality (three RCTs scored 4-5 points, five retrospective studies scored 9 points, 14 retrospective studies scored 8 points) and nine studies were of medium quality (seven retrospective studies scored 7 points, two retrospective studies scored 6 points) (Table 1). Table 2 summarizes the baseline characteristics and main evaluation indices of the included studies. 


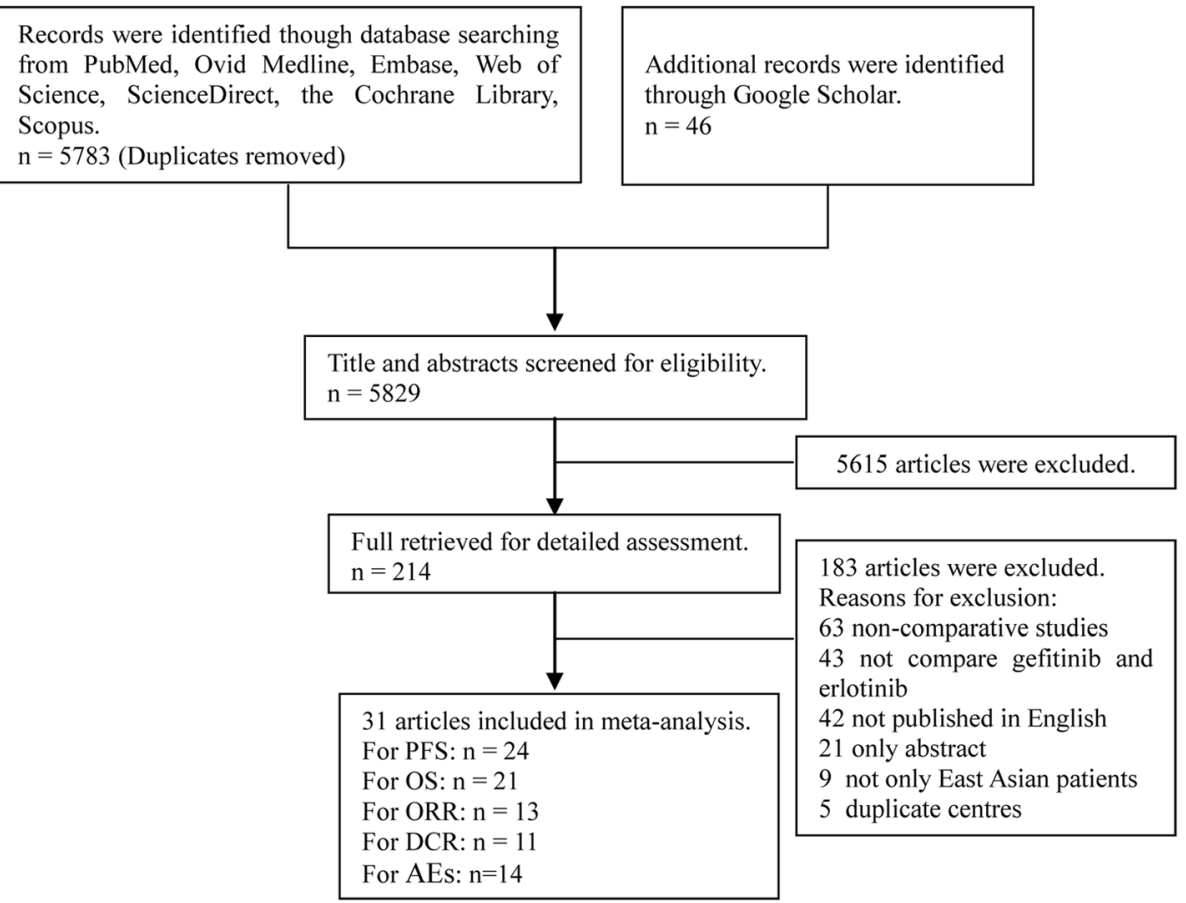

Fig. 1 Flow chart of study selection

\section{Anti-tumor efficacy}

We assessed anti-tumor efficacy between the gefitinib and erlotinib groups based on PFS, OS, ORR, and DCR.

Twenty-four studies compared PFS (heterogeneity: $\left.p=0.03, I^{2}=38 \%\right)$. No significant difference was found between the two groups (95\% CI: $0.97-1.10, p=0.26$; Fig. 2).

Twenty-one studies compared OS (heterogeneity: $p=$ $\left.0.0004, I^{2}=58 \%\right)$. No significant difference was found between the two groups (95\% CI: $0.89-1.21, p=0.61$; Fig. 3).

Thirteen studies compared ORR (heterogeneity: $p=$ $\left.0.24, I^{2}=20 \%\right)$. No significant difference was found between the two groups (95\% CI: 1.00-1.18, $p=0.06$; Fig. 4a).

Eleven studies compared DCR (heterogeneity: $p=0.17$, $\left.I^{2}=29 \%\right)$. No significant difference was found between the two groups (95\% CI: $0.93-1.05, p=0.68$; Fig. $4 \mathrm{~b}$ ).

\section{Toxicity}

We compared toxicity between the gefitinib and erlotinib groups based on total AEs, grade 3-5 AEs, and subgroup analysis of the 10 most reported AEs.

Five studies compared total AEs (heterogeneity: $p=$ $\left.0.0007, I^{2}=79 \%\right)$. No significant difference was found between the two groups (95\% CI: 0.87-1.13, $p=0.94$; Fig. 5a).

Seven studies compared grade 3-5 AEs (heterogeneity: $\left.p=0.001, I^{2}=73 \%\right)$. The gefitinib group had a significantly lower incidence rate of grade 3-5 AEs than the erlotinib group (95\% CI: $0.27-0.71, p=0.0008$; Fig. 5b). Some patients had drug discontinuations/reductions due to the occurrence of serious AEs. Two studies compared drug discontinuations; there was no significant difference between the two groups (95\% CI: 0.40-1.80, $p=0.68$; Fig. 6a). Four studies compared drug reductions; the erlotinib group had more drug reductions (95\% CI: 0.13-0.65, $p=0.002$; Fig. 6b).

In subgroup analysis of the 10 most reported AEs (skin rash, diarrhea, nausea/vomiting, fatigue, anorexia, interstitial lung disease, stomatitis, elevated liver enzymes, infection, neutropenia), the results for all-grade AEs showed no significant differences in anorexia, interstitial lung disease, elevated liver enzymes, infection, neutropenia and nausea/vomiting between the two groups. For all-grade AEs, erlotinib induced significantly higher rates of skin rash (95\% CI: 0.74-0.94, $p=0.003)$, diarrhea (95\% CI: $0.73-0.95, p=0.005)$, fatigue (95\% CI: $0.23-$ $0.95, p=0.04)$, and stomatitis (95\% CI: $0.15-0.54, p=$ 0.0001 ) (Table 3 ). The results for grade 3-5 AEs showed no significant differences in anorexia, interstitial lung disease, elevated liver enzymes, infection, and neutropenia between the two groups. For grade 3-5 AEs, erlotinib induced significantly higher rates of skin rash (95\% CI: 0.12-0.41, $p<0.00001$ ), diarrhea (95\% CI: $0.29-0.74, p=0.001$ ), nausea/vomiting (95\% CI: $0.11-$ $0.49, p=0.0001$ ), fatigue (95\% CI: $0.09-0.87, p=0.03$ ), and stomatitis (95\% CI: 0.08-0.99, $p=0.05$ ) (Table 4). 
Table 1 Quality assessment of all included studies

\begin{tabular}{|c|c|c|c|c|c|c|c|c|}
\hline \multirow{2}{*}{\multicolumn{2}{|c|}{$\frac{\text { Study }}{\text { Randomized controlled tria }}$}} & \multirow{2}{*}{ Selection } & \multirow[t]{2}{*}{ Comparability } & \multirow[t]{2}{*}{ Exposure } & \multirow[t]{2}{*}{ Randomization } & \multirow[t]{2}{*}{ Masking } & \multirow[t]{2}{*}{ Accountability of all patients } & \multirow[t]{2}{*}{ Quality (score) } \\
\hline & & & & & & & & \\
\hline 2012 & Kim [26] & & & & $\star \star$ & $\star$ & $\star$ & 4 \\
\hline 2016 & Urata [10] & & & & $\star \star$ & $\star \star$ & $\star$ & 5 \\
\hline 2017 & Yang [11] & & & & $\star \star$ & $\star \star$ & $\star$ & 5 \\
\hline \multicolumn{9}{|c|}{ Retrospective study } \\
\hline 2010 & Kim [19] & $\star \star \star$ & $\star \star$ & $\star \star$ & & & & 7 \\
\hline 2010 & Hotta [20] & $\star \star \star \star$ & $\star \star$ & $\star \star \star$ & & & & 9 \\
\hline 2010 & Hong [21] & $\star \star \star$ & $\star \star$ & $\star \star$ & & & & 7 \\
\hline 2011 & Wu [22] & $\star \star \star \star$ & $\star \star$ & $\star \star \star$ & & & & 9 \\
\hline 2011 & Shin [12] & $\star \star \star$ & $\star \star$ & $\star \star$ & & & & 7 \\
\hline 2011 & Togashi [23] & $\star \star \star \star$ & $\star \star$ & $\star \star$ & & & & 8 \\
\hline 2011 & Fan [14] & $\star \star \star \star$ & $\star \star$ & $\star \star$ & & & & 8 \\
\hline 2011 & Jung [24] & $\star \star \star$ & $\star \star$ & $\star$ & & & & 6 \\
\hline 2012 & $\mathrm{Wu}[25]$ & $\star \star \star \star$ & $\star \star$ & $\star \star$ & & & & 8 \\
\hline 2012 & Suzumura [27] & $\star \star \star$ & $\star \star$ & $\star \star \star$ & & & & 8 \\
\hline 2013 & Yoshida [28] & $\star \star \star \star$ & $\star \star$ & $\star \star$ & & & & 8 \\
\hline 2013 & Shao [29] & $\star \star \star \star$ & $\star \star$ & $\star \star \star$ & & & & 9 \\
\hline 2013 & Lee [30] & $\star \star \star \star$ & $\star \star$ & $\star \star$ & & & & 8 \\
\hline 2013 & Yu [31] & $\star \star \star \star$ & $\star \star$ & $\star \star$ & & & & 8 \\
\hline 2014 & Lim [32] & $\star \star \star \star$ & $\star \star$ & $\star \star \star$ & & & & 9 \\
\hline 2014 & Sato [13] & $\star \star \star \star$ & $\star \star$ & $\star \star$ & & & & 8 \\
\hline 2014 & Lin [33] & $\star \star \star$ & $\star \star$ & $\star \star$ & & & & 7 \\
\hline 2014 & Ren [34] & $\star \star \star \star$ & $\star \star$ & $\star \star$ & & & & 8 \\
\hline 2014 & Li [35] & $\star \star \star$ & $\star \star$ & $\star \star \star$ & & & & 8 \\
\hline 2014 & Takeda [36] & $\star \star \star$ & $\star \star$ & $\star$ & & & & 6 \\
\hline 2015 & Otsuka [37] & $\star \star \star \star$ & $\star \star$ & $\star \star \star$ & & & & 9 \\
\hline 2015 & Song [38] & $\star \star \star$ & $\star \star$ & $\star \star$ & & & & 7 \\
\hline 2015 & Koo [39] & $\star \star \star \star$ & $\star \star$ & $\star$ & & & & 7 \\
\hline 2016 & Ruan [40] & $\star \star \star$ & $\star \star$ & $\star \star \star$ & & & & 8 \\
\hline 2016 & Hirano [41] & $\star \star \star$ & $\star \star$ & $\star \star \star$ & & & & 8 \\
\hline 2016 & Suh [42] & $\star \star \star$ & $\star \star$ & $\star \star$ & & & & 7 \\
\hline 2016 & Kashima [43] & $\star \star \star$ & $\star \star$ & $\star \star \star$ & & & & 8 \\
\hline 2017 & Kuan [15] & 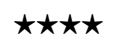 & $\star \star$ & $\star \star$ & & & & 8 \\
\hline
\end{tabular}

\section{Subgroup analysis}

To determine whether the anti-tumor efficacy of gefitinib versus erlotinib was consistent across subgroups, the pooled efficacy for PFS, OS, and ORR was estimated within each category of the following classification variables: country, tumor stage, histology, line of treatment, EGFR mutation status, and study design. All subgroup differences were not statistically significant in terms of PFS, OS, and ORR between the gefitinib and erlotinib groups (Table 5).

\section{Sensitivity analysis}

Significant heterogeneity was found in the analysis of OS, total AEs and grade 3-5 AEs. The influence of each study on the pooled results was evaluated to evaluate stability and sensitivity. The results suggested that the outcomes of OS, total AEs and grade 3-5 AEs were reliable and stable (Fig. 7).

\section{Cumulative meta-analysis}

Analyses of PFS (Additional file 1: Figure S1), OS (Additional file 2: Figure S2), ORR (Additional file 3: 
Table 2 Characteristics of included studies

\begin{tabular}{|c|c|c|c|c|c|c|c|c|c|c|c|}
\hline Study & & Country & Groups & $\begin{array}{l}\text { Patients } \\
\text { (n) }\end{array}$ & $\begin{array}{l}\text { Median age } \\
\text { (year) }\end{array}$ & Stage & $\begin{array}{l}\text { Treatment } \\
\text { line }\end{array}$ & EGFRmutations & $\begin{array}{l}\text { Adenocarcinoma } \\
(\%)\end{array}$ & Design & $\begin{array}{l}\text { Quality } \\
\text { (score) }\end{array}$ \\
\hline 2010 & Kim [19] & Korea & G vs. E & 171/171 & $58 / 59$ & IIIb, IV & 2,3 & - & 86 & RS & 7 \\
\hline 2010 & Hotta [20] & Japan & G vs. E & $330 / 209$ & $68 / 68$ & $\begin{array}{l}\text { II-IV or } \\
\text { recurrent }\end{array}$ & 2,3 & - & 76 & RS & 9 \\
\hline 2010 & Hong [21] & Keroa & G vs. E & $20 / 17$ & $61 / 67$ & IIIb, IV & 2,3 & - & 75 & RS & 7 \\
\hline 2011 & Wu [22] & Taiwan & G vs. E & $440 / 276$ & $67 / 67$ & IIIb, IV & 1 or later & Partial & 85 & RS & 9 \\
\hline 2011 & Shin [12] & Keroa & G vs. E & $100 / 82$ & $65 / 65$ & III, IV & 2 & Partial & 0 & RS & 7 \\
\hline 2011 & Togashi [23] & Japan & G vs. E & $85 / 69$ & $65 / 68$ & IIIb, IV & 1 or later & Partial & 82 & RS & 8 \\
\hline 2011 & Fan [14] & Taiwan & G vs. E & $715 / 407$ & - & IIIb, IV & 1 or later & Partial & 77 & RS & 8 \\
\hline 2011 & Jung [24] & Korea & G vs. E & $72 / 51$ & $55 / 55$ & Illb, IV & 1 or later & Partial & 59 & RS & 6 \\
\hline 2012 & Wu [25] & Taiwan & G vs. E & $124 / 100$ & - & IIIb, IV & 1 or later & Partial & 100 & RS & 8 \\
\hline 2012 & Kim [26] & Keroa & G vs. E & $48 / 48$ & $59 / 60$ & Illb, IV & 2 & Partial & 91 & $\mathrm{RCT}$ & 4 \\
\hline 2012 & Suzumura [27] & Japan & G vs. E & $232 / 86$ & $67 / 66$ & IIIb, IV & - & Partial & 95 & RS & 8 \\
\hline 2013 & Yoshida [28] & Japan & G vs. E & $107 / 35$ & $64 / 67$ & $\begin{array}{l}\text { III, IV or } \\
\text { recurrent }\end{array}$ & 1 or later & Partial & 84 & RS & 8 \\
\hline 2013 & Shao [29] & Taiwan & G vs. E & $655 / 329$ & $61 / 63$ & $\begin{array}{l}\text { IIlb, IV or } \\
\text { recurrent }\end{array}$ & 3 & - & 80 & RS & 9 \\
\hline 2013 & Lee [30] & Korea & G vs. E & $11 / 14$ & $49 / 58$ & IV & 1 or later & Partial & 92 & RS & 8 \\
\hline 2013 & Yu [31] & China & G vs. E & $16 / 22$ & $54 / 52$ & - & 3 & Partial & 100 & RS & 8 \\
\hline 2014 & Lim [32] & Korea & G vs. E & $121 / 121$ & $58 / 58$ & IIIb, IV & 1 or later & All & 98 & RS & 9 \\
\hline 2014 & Sato [13] & Japan & G vs. E & $213 / 69$ & $66 / 66$ & $\begin{array}{l}\text { Illb, IV or } \\
\text { recurrent }\end{array}$ & - & Partial & 86 & RS & 8 \\
\hline 2014 & Lin [33] & China & G vs. E & $57 / 24$ & - & Illb, IV & 1 & All & 59 & RS & 7 \\
\hline 2014 & Ren [34] & China & G vs. E & $60 / 142$ & $59 / 59$ & IV & 1 or later & Partial & 66 & RS & 8 \\
\hline 2014 & Li [35] & China & G vs. E & $53 / 97$ & $59 / 59$ & IIIb, IV & 2 & Partial & 67 & RS & 8 \\
\hline 2014 & Takeda [36] & Japan & G vs. E & $57 / 11$ & $69 / 69$ & III, IV or recurrent & 1 or later & All & 99 & RS & 6 \\
\hline 2015 & Otsuka [37] & Japan & G vs. E & $35 / 9$ & $70 / 62$ & IIIb, IV & 1 or later & All & 91 & RS & 9 \\
\hline 2015 & Song [38] & China & G vs. E & $37 / 65$ & $75 / 75$ & IIIb, IV & 2 or later & Partial & 83 & RS & 7 \\
\hline 2015 & Koo [39] & Korea & G vs. E & $166 / 56$ & - & IV & $1,2,3$ & All & 87 & RS & 7 \\
\hline 2016 & Ruan [40] & China & G vs. E & $63 / 134$ & $59 / 60$ & III, IV & - & All & - & RS & 8 \\
\hline 2016 & Hirano [41] & Japan & G vs. E & $10 / 16$ & $71 / 71$ & IB-IV or recurrent & - & All & 81 & RS & 8 \\
\hline 2016 & Urata [10] & Japan & G vs. E & $279 / 280$ & $68 / 67$ & $\begin{array}{l}\text { Illb, IV or } \\
\text { recurrent }\end{array}$ & 2,3 & Partial & 100 & $\mathrm{RCT}$ & 5 \\
\hline 2016 & Suh [42] & Korea & G vs. E & $146 / 5$ & $65 / 65$ & IIIb, IV & 1 & All & 97 & RS & 7 \\
\hline 2016 & Kashima [43] & Japan & G vs. E & $52 / 11$ & $68 / 68$ & IV & - & All & - & RS & 8 \\
\hline 2017 & Yang [11] & China & G vs. E & $128 / 128$ & - & IIIb, IV & 1,2 & All & 96 & $\mathrm{RCT}$ & 5 \\
\hline 2017 & Kuan [15] & Taiwan & G vs. E & $304 / 63$ & $65 / 67$ & IIIb, IV & 1 & All & - & RS & 8 \\
\hline
\end{tabular}

Abbreviations: $G$ gefitinib, E erlotinib, EGFR epidermal growth factor receptor, $R S$ retrospective study, $R C T$ randomized controlled trial, -: not available

Figure S3), DCR (Additional file 4: Figure S4) and total AEs (Additional file 5: Figure S5) demonstrated that the RRs of the final results became robust within a narrow range and remained not significant as publication years increased and as recent high-quality studies were included. After inclusion of Shin et al.'s study [12], the RR and 95\% CI for grade 3-5 AEs decreased to $<1$ and became stable (Additional file 6: Figure S6). Although there was no significantly reduced risk in ORR, clear evidence showed that the confidence interval was becoming narrow, and trended toward significance (favors gefitinib).

\section{Publication bias}

There was no evidence of publication bias for PFS (Begg's test $p=0.585$; Egger's test $p=0.477$, Fig. 8a) and OS (Begg's test $p=0.880$; Egger's test $p=0.798$, Fig. $8 \mathrm{~b}$ ). 


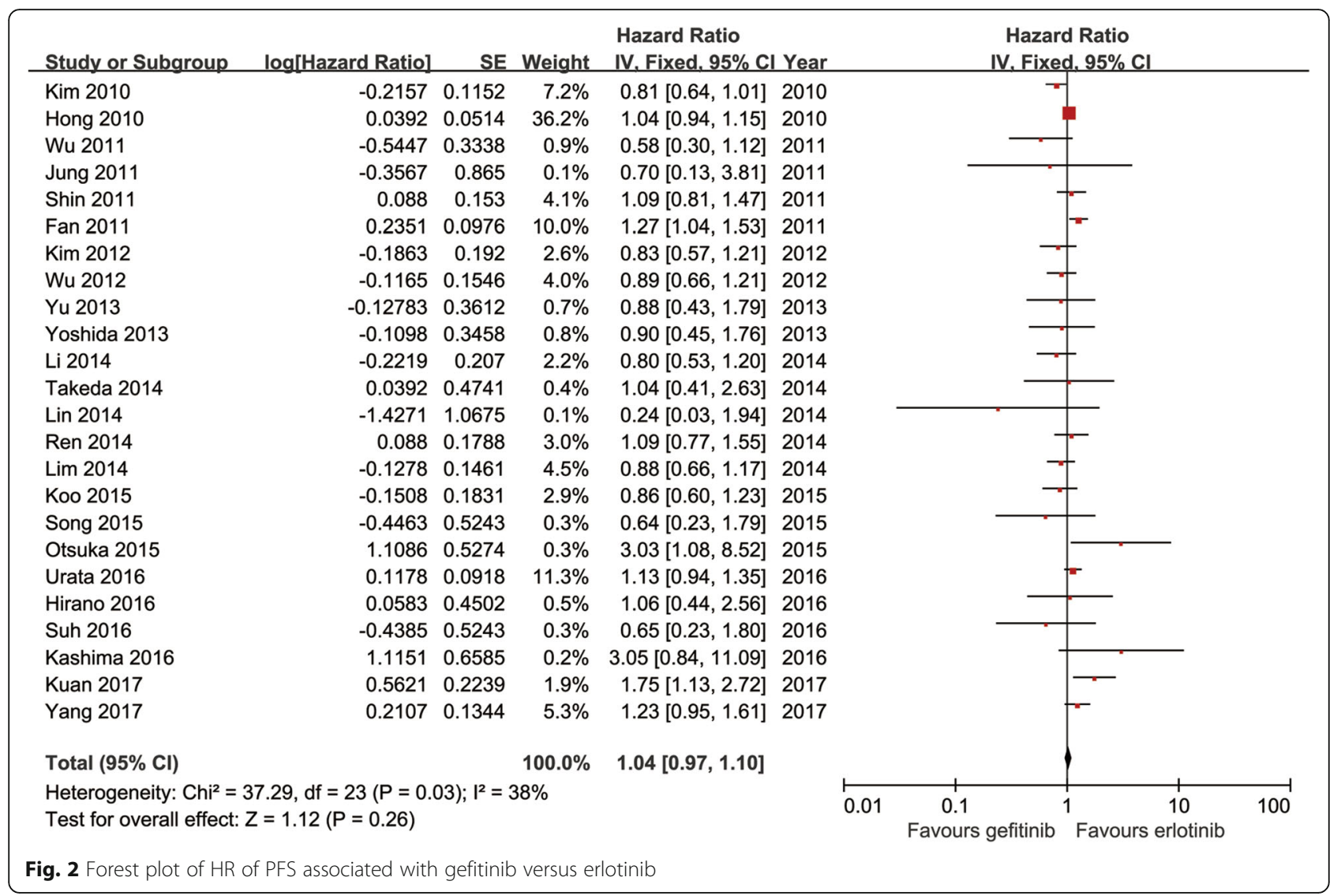

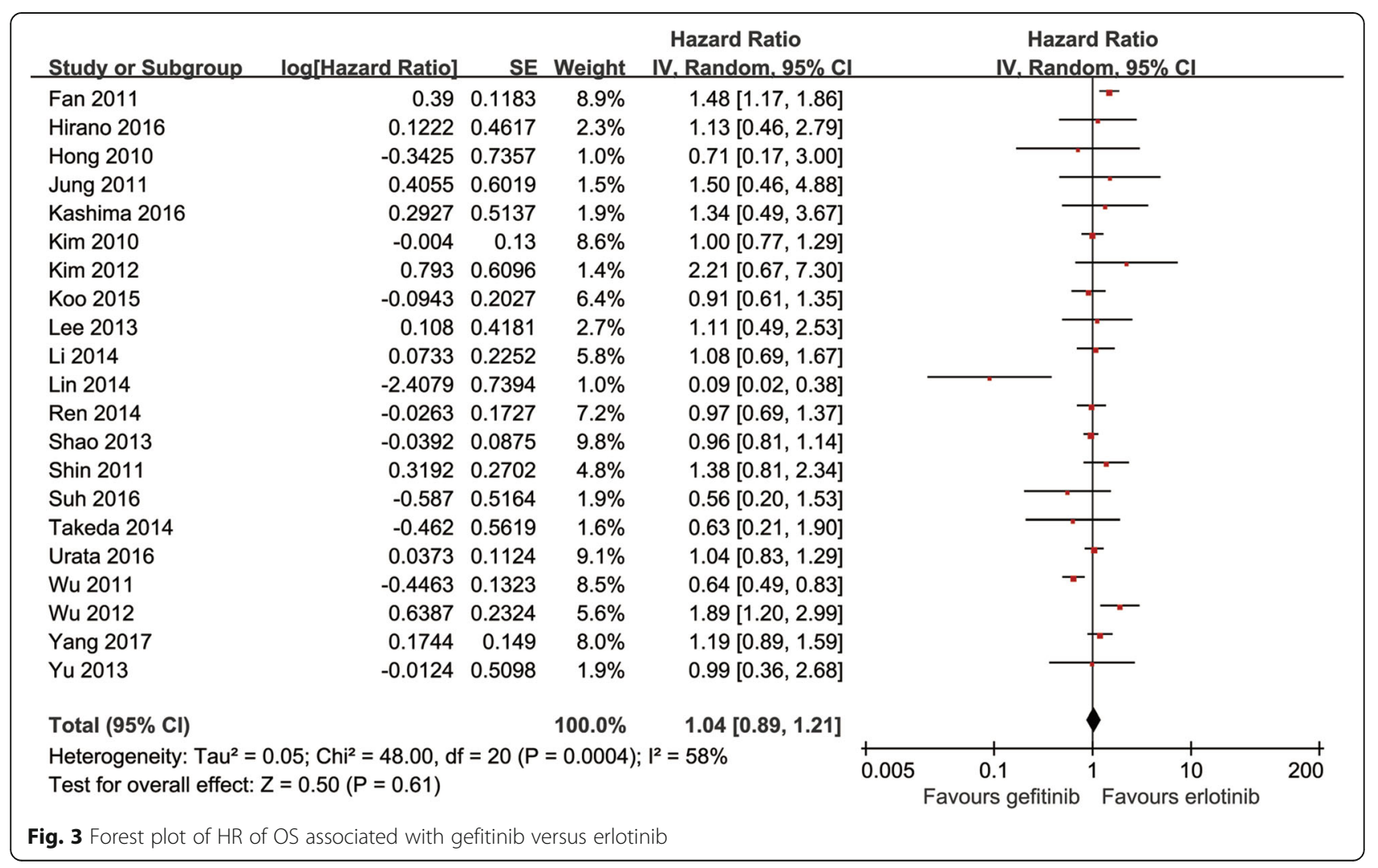




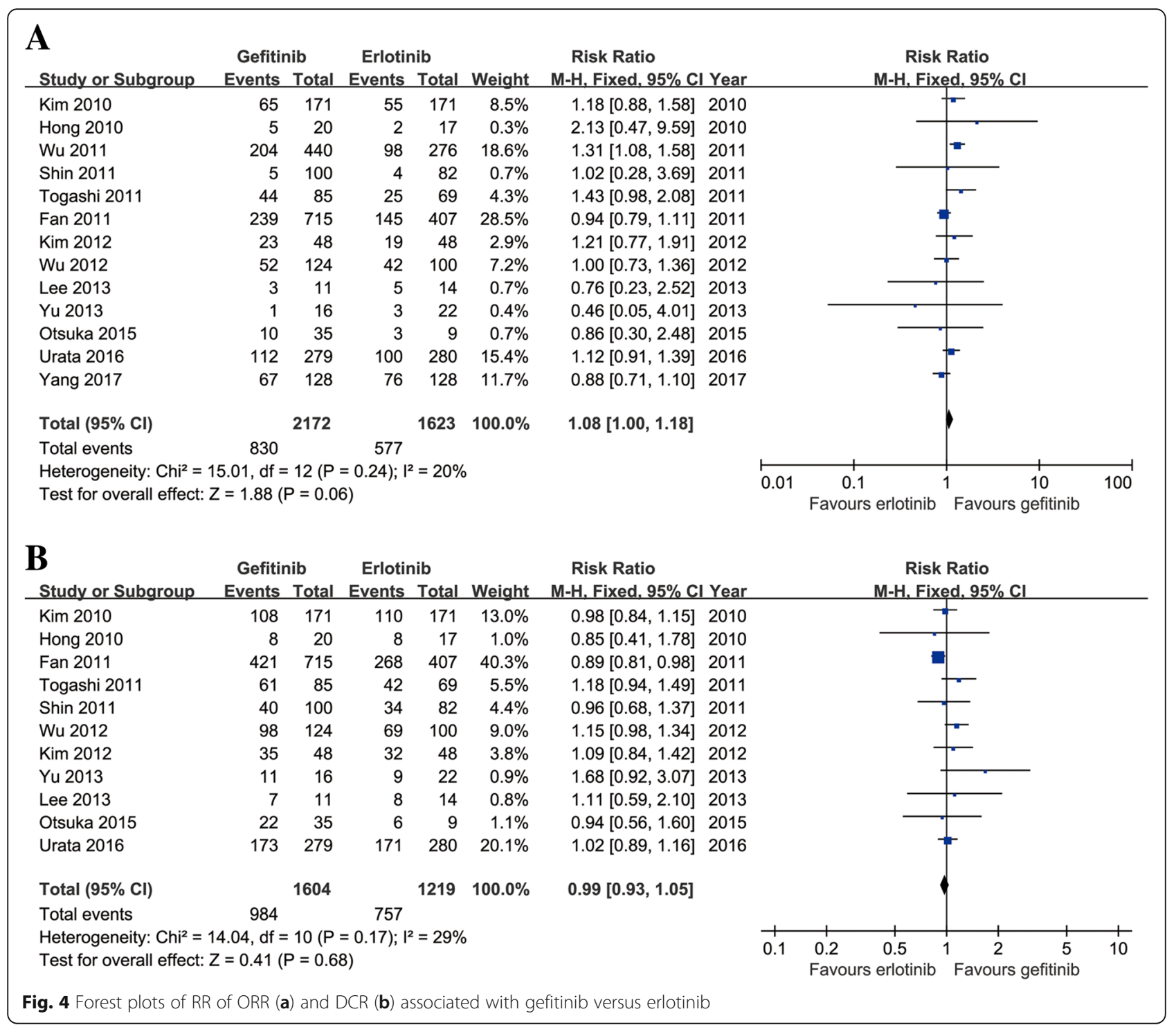

\section{Discussion}

Gefitinib and erlotinib are two similar small molecules with different binding capabilities and pharmacokinetic and pharmacodynamic properties related to their differing molecular structures [44-46]. Whether the differences between these first-generation EGFR TKIs can cause different anti-tumor efficacy is controversial [10, 11, 47]. By analyzing 31 high-quality studies, we directly compared the anti-tumor efficacy and safety of gefitinib and erlotinib for treating NSCLC $[10-15,19-43]$. Our meta-analysis provides the most current medical evidence and shows that anti-tumor efficacy (PFS, OS, ORR, DCR) is comparable between gefitinib and erlotinib for treating East Asian patients with NSCLC. Subgroup analysis according to country, tumor stage, histology, line of treatment, EGFR mutation, and study design did not change the results. However, erlotinib toxicity was significantly greater than that of gefitinib, especially in all-grade/grade 3-4 skin rash, nausea/vomiting, fatigue, and stomatitis.

The greater drug toxicity is an critical problem regarding erlotinib. In our analysis, we found high incidences of drug reduction, skin rash, diarrhea, nausea/vomiting, fatigue, and stomatitis in the erlotinib arm. Although it might not decrease survival time, it greatly reduces patients' quality of life $[48,49]$. We believe there are two reasons for these results: (1) the oral dose of erlotinib (150 mg/day) was closer to the maximum tolerated dose (150 mg/day) as compared with gefitinib (oral dose, $250 \mathrm{mg} /$ day; maximum tolerated dose, $600 \mathrm{mg} /$ day) [50, 51]; (2) The two EGFR TKIs have different pharmacokinetics. After absorption, more gefitinib accumulates in tumor tissue than in plasma; the opposite is true for erlotinib [52]. In the published literature, more severe AEs have been reported in East Asian patients as 


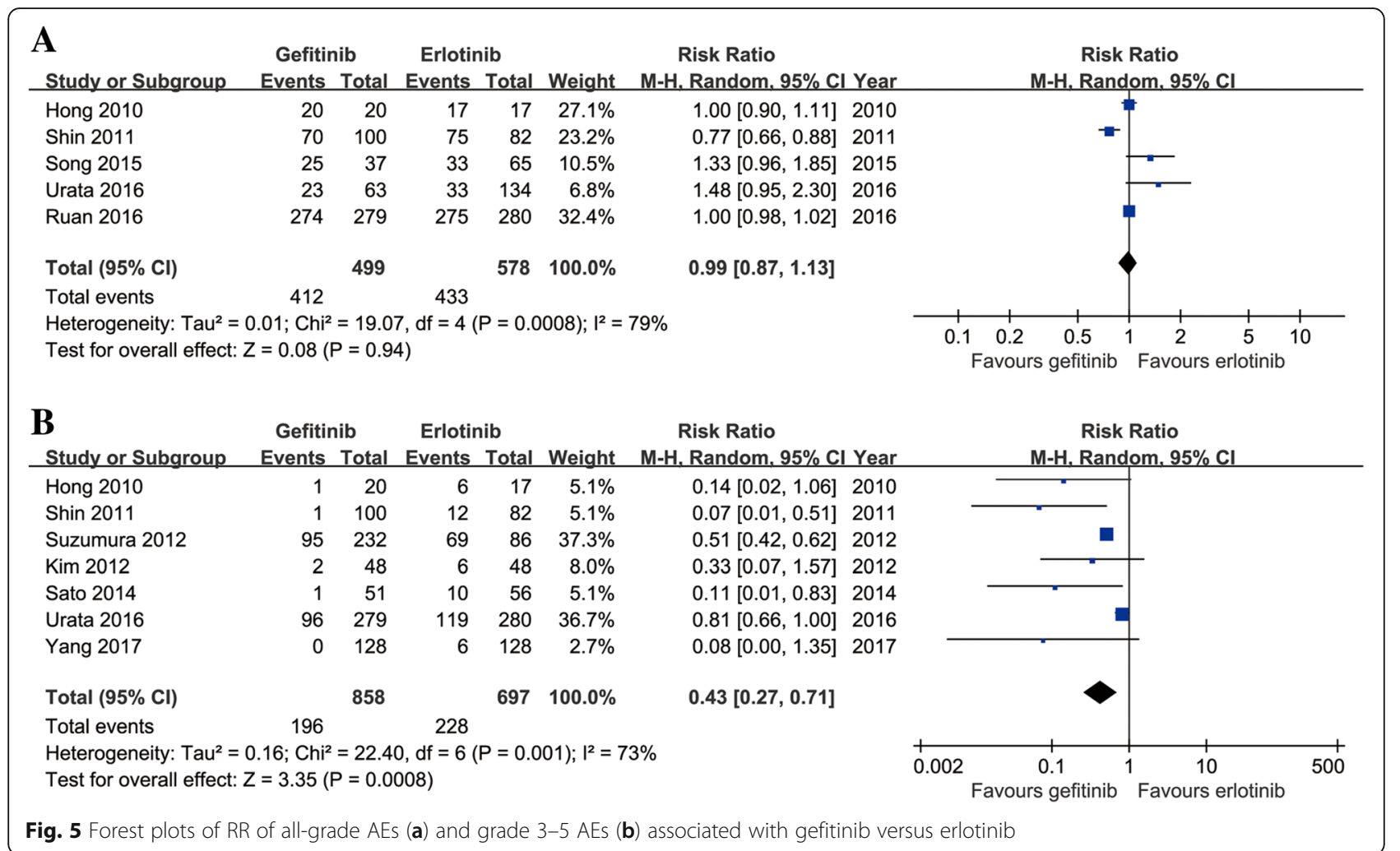

compared with patients from Europe and America [9, 53]. Interstitial lung disease is one of the most important AEs, and can cause worse prognosis and increased risk of death [54]. However, our analysis and other published studies show that most cases of interstitial lung disease are reported in East Asian populations and that it is rare in
Western populations. This might be attributed to the smaller physiques of Asians in general. In a retrospective study, Yeo reduced the erlotinib dose to $25 \mathrm{mg} /$ day and achieved similar or even better prognosis as compared with the standard dose [55]. Other retrospective studies have reported similar results [13, 56-58]. Accordingly, we

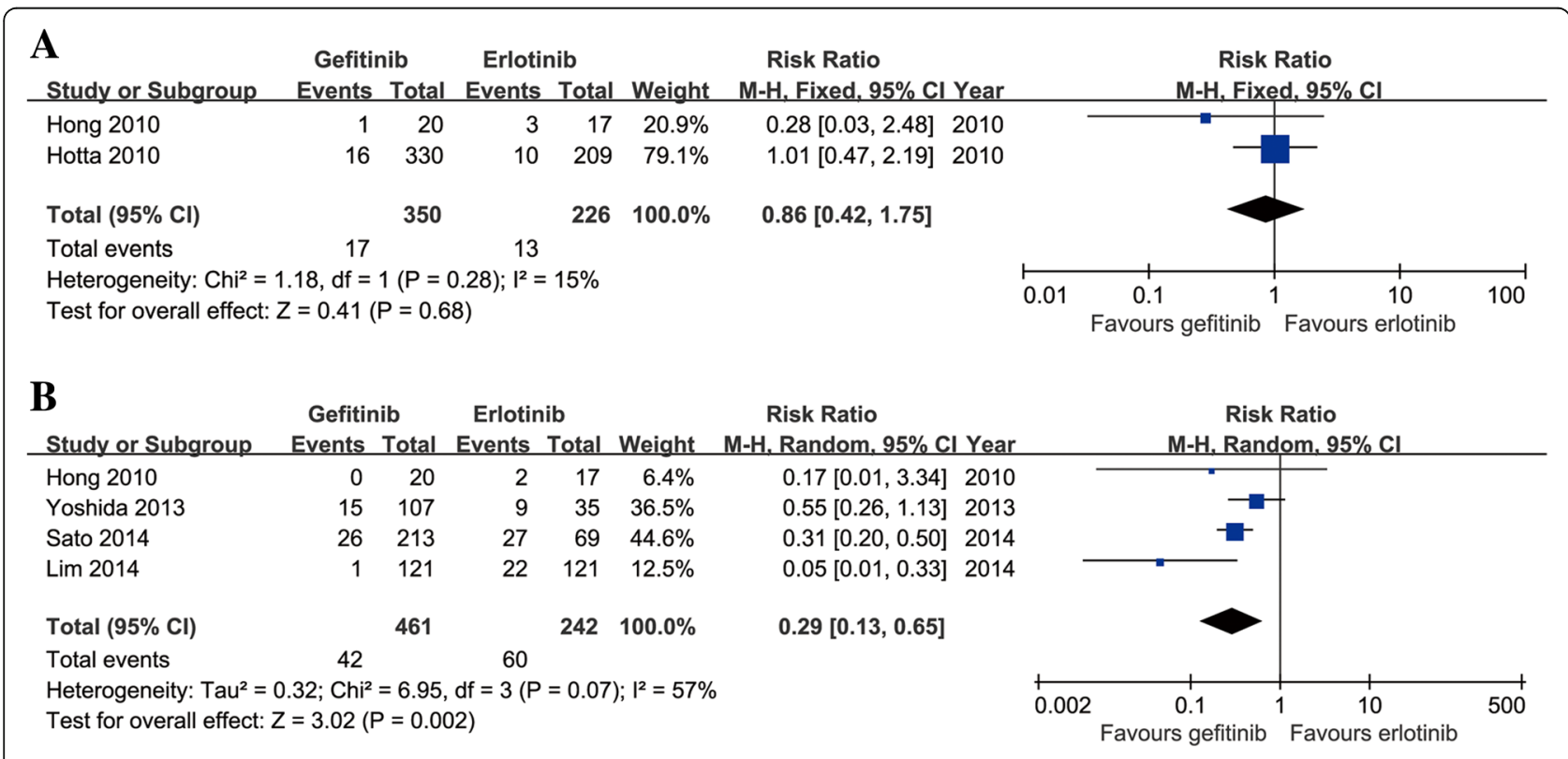

Fig. 6 Forest plots of RR of drug discontinuations (a) and drug reductions (b) associated with gefitinib versus erlotinib 
Table 3 Top 10 adverse effects (all grade) associated with gefitinib versus erlotinib

\begin{tabular}{|c|c|c|c|c|c|c|}
\hline \multirow[t]{2}{*}{ Adverse effects } & \multirow{2}{*}{$\begin{array}{l}\text { Gefitinib group } \\
\text { (event/total) }\end{array}$} & \multirow{2}{*}{$\begin{array}{l}\text { Erlotinib group } \\
\text { (event/total) }\end{array}$} & \multirow[t]{2}{*}{ RR $(95 \% \mathrm{Cl})$} & \multirow[t]{2}{*}{$P$ value } & \multicolumn{2}{|c|}{ Heterogeneity } \\
\hline & & & & & $P(\%)$ & $P$ value \\
\hline Skin rash & 673/1099 & $650 / 944$ & $0.83(0.74-0.94)$ & 0.003 & 68 & 0.0009 \\
\hline Diarrhea & 298/999 & $273 / 745$ & $0.83(0.73-0.95)$ & 0.005 & 47 & 0.06 \\
\hline Nausea/Nomiting & $107 / 639$ & $139 / 531$ & $0.71(0.32-1.57)$ & 0.4 & 74 & 0.002 \\
\hline Fatigue & $124 / 639$ & $149 / 531$ & $0.47(0.23-0.95)$ & 0.04 & 81 & $<0.0001$ \\
\hline Anorexia & $53 / 403$ & $40 / 310$ & $0.98(0.40-2.42)$ & 0.97 & 78 & 0.001 \\
\hline Interstitial lung disease & $35 / 949$ & $19 / 723$ & $1.38(0.78-2.44)$ & 0.26 & 0 & 0.65 \\
\hline Stomatitis & $12 / 260$ & 29/169 & $0.29(0.15-0.54)$ & 0.0001 & 24 & 0.27 \\
\hline Elevated liver enzymes & $366 / 931$ & $264 / 680$ & $1.16(0.85-0.1 .56)$ & 0.35 & 61 & 0.04 \\
\hline Infection & $45 / 686$ & $23 / 466$ & $1.53(0.93-2.51)$ & 0.1 & 23 & 0.27 \\
\hline Neutropenia & $61 / 399$ & $51 / 379$ & $1.19(0.85-1.66)$ & 0.32 & 0 & 0.55 \\
\hline
\end{tabular}

suggest that individualized drug dose based on weight or body surface area might be more appropriate than a fixed oral dose for treating advanced NSCLC. More large-sample, well-designed RCTs are needed to confirm the best dose of gefitinib and erlotinib for East Asian patients with advanced NSCLC.

Almost all of the included studies did not show any differences in all anti-tumor efficacy indices, which formed the basis of our results. Only one study reported an unfavorable result for erlotinib, with both lower PFS and OS, which might relate to the erlotinib group having more patients with non-adenocarcinoma NSCLC as based on government regulations [14]. Our results also showed a trend for prolonged median PFS (gefitinib group, 7.1 months vs. 4.9 months; erlotinib group, 7.7 months vs. 3.4 months) and OS (gefitinib group, 19.1 months vs. 14.0 months; erlotinib group, 15.5 months vs. 12.7 months) in patients with adenocarcinoma as compared with squamous-included NSCLC. However, no difference was found between gefitinib and erlotinib in this subgroup.
In the EGFR mutation status subgroup, we also found no difference between the anti-tumor efficacy of gefitinib and erlotinib. However, our results indirectly prove that both gefitinib and erlotinib are more suitable for treating EGFR mutation-positive NSCLC. Both median PFS (gefitinib group, 11.4 months vs. 4.9 months; erlotinib group, 9.6 months vs. 3.1 months) and OS (gefitinib group, 22.6 months vs. 16.0 months; erlotinib group, 20.9 months vs. 12.0 months) were longer in the EGFR mutation-positive subgroup than in the partial EGFR mutation-positive subgroup. Accordingly, we observed that the proportion of EGFR mutations increased by the year in EGFR TKI treatment (Table 1). Multiple EGFR mutation isoforms (exon 19, exon 21, others) were found, although the isoform most susceptible to gefitinib or erlotinib remains unclear. A phase III RCT compared gefitinib and erlotinib treatment in EGFR mutationpositive NSCLC and found significantly higher RR and longer median OS for patients with EGFR exon $19 \mathrm{mu}$ tations than for patients with EGFR exon 21 mutations following erlotinib or gefitinib treatment. However, no

Table 4 Top 10 adverse effects (grade 3-5) associated with gefitinib versus erlotinib

\begin{tabular}{|c|c|c|c|c|c|c|}
\hline \multirow{2}{*}{$\begin{array}{l}\text { Grade } 3-5 \text { Adverse } \\
\text { effects }\end{array}$} & \multirow{2}{*}{$\begin{array}{l}\text { Gefitinib group } \\
\text { (event/total) }\end{array}$} & \multirow{2}{*}{$\begin{array}{l}\text { Erlotinib group } \\
\text { (event/total) }\end{array}$} & \multirow[t]{2}{*}{ RR (95\% Cl) } & \multirow[t]{2}{*}{$P$ value } & \multicolumn{2}{|c|}{ Heterogeneity } \\
\hline & & & & & $P(\%)$ & $P$ value \\
\hline Skin rash & 72/999 & $163 / 745$ & $0.22(0.12-0.41)$ & $<0.00001$ & 73 & 0.0006 \\
\hline Diarrhea & $31 / 892$ & $38 / 710$ & $0.46(0.29-0.74)$ & 0.001 & 0 & 0.46 \\
\hline Nausea/Nomiting & $8 / 639$ & $27 / 531$ & $0.23(0.11-0.49)$ & 0.0001 & 20 & 0.29 \\
\hline Fatigue & $18 / 639$ & $40 / 531$ & $0.28(0.09-0.87)$ & 0.03 & 74 & 0.02 \\
\hline Anorexia & $3 / 403$ & $4 / 310$ & $0.25(0.06-1.04)$ & 0.06 & NA & NA \\
\hline Interstitial lung disease & $7 / 619$ & $3 / 514$ & $1.05(0.27-4.06)$ & 0.95 & 17 & 0.3 \\
\hline Stomatitis & $3 / 260$ & $8 / 169$ & $0.28(0.08-0.99)$ & 0.05 & 24 & 0.27 \\
\hline Elevated liver enzymes & $80 / 652$ & $23 / 400$ & $1.50(0.97-2.31)$ & 0.07 & 0 & 0.64 \\
\hline Infection & $9 / 454$ & $7 / 380$ & $1.12(0.46-2.69)$ & 0.8 & 20 & 0.28 \\
\hline Neutropenia & $2 / 399$ & $3 / 379$ & $0.67(0.11-3.97)$ & 0.66 & NA & NA \\
\hline
\end{tabular}




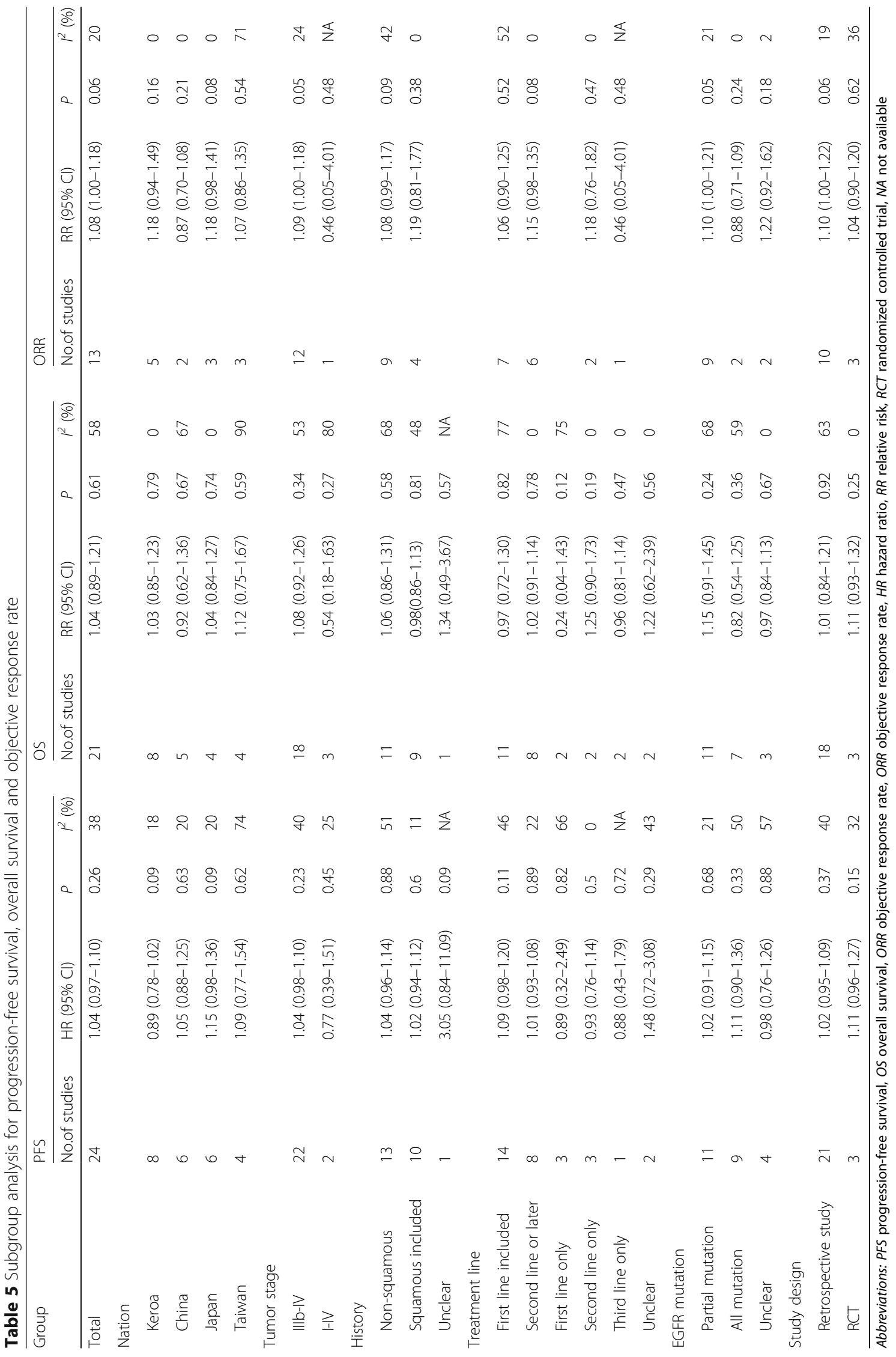




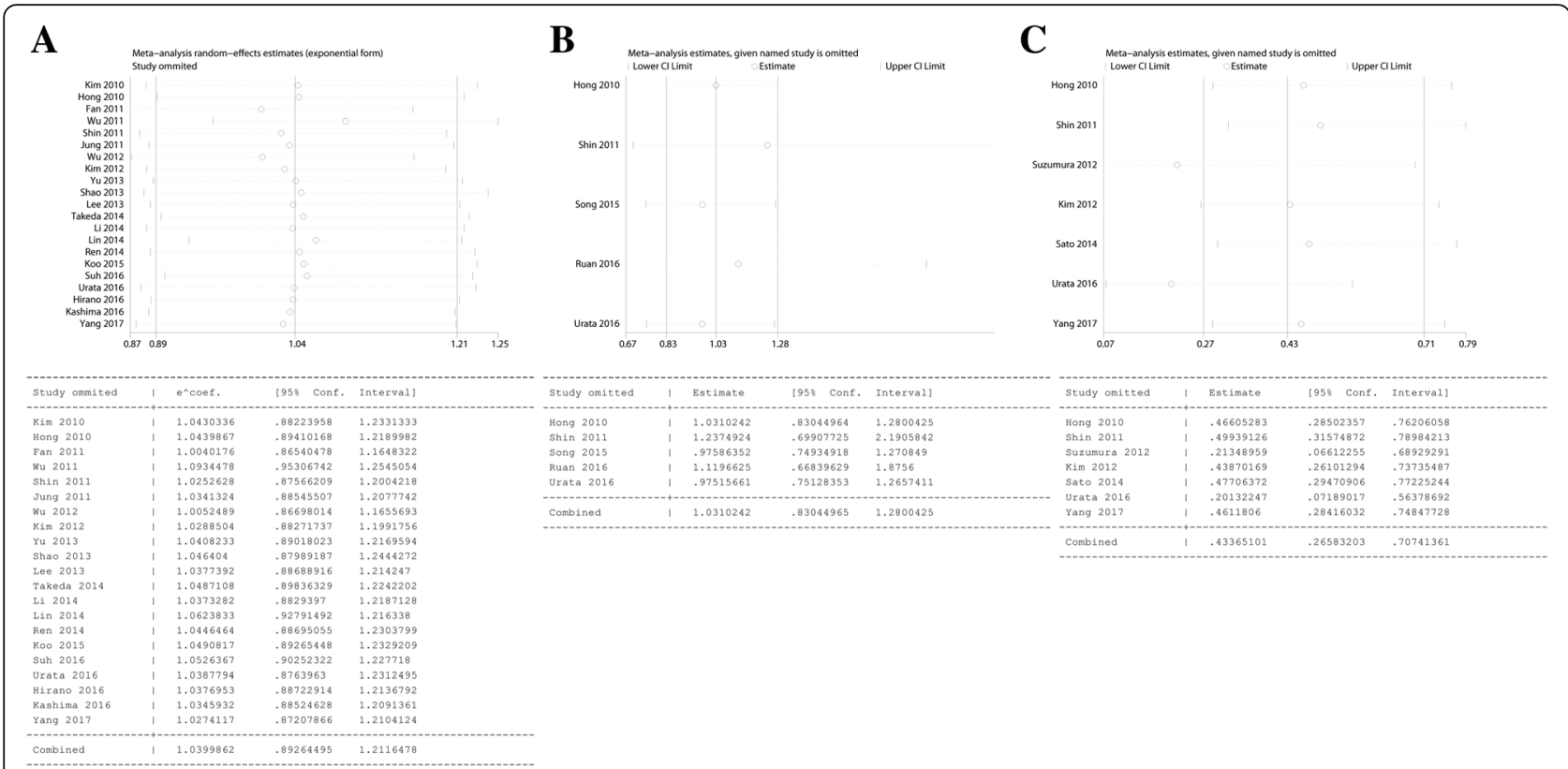

Fig. 7 Meta-based influence analysis for comparisons of OS (a), total AEs (b) and grade 3-5 AEs (c)

difference was found between gefitinib and erlotinib for both mutations [11]. Another RCT involving more EGFR mutation isoforms (exon 19, exon 21, T790 M) reported similar results [10]. However, Kuan suggested that erlotinib is associated with significantly longer PFS and lower risk of progression than gefitinib in patients with EGFR exon 19 deletions [15]. Limited by the quantity of published studies and included patients, further large-sample, well-designed RCTs focusing on single EGFR mutations are warranted to identify the best EGFR TKIs.
The line of treatment in which EGFR TKIs should be used in NSCLC remains controversial. Mainstream thinking considers EGFR TKIs second-line or later treatment after chemotherapy failure or first-line treatment for patients unable to tolerate chemotherapy. However, Table 1 shows that an increasing number of studies have used gefitinib and erlotinib as first-line treatment for advanced NSCLC [15, 33, 42]. However, no differences were found for PFS, OS, and ORR between gefitinib and erlotinib in each line of treatment subgroup. Wu et al. conducted a phase III RCT and suggested that first-line
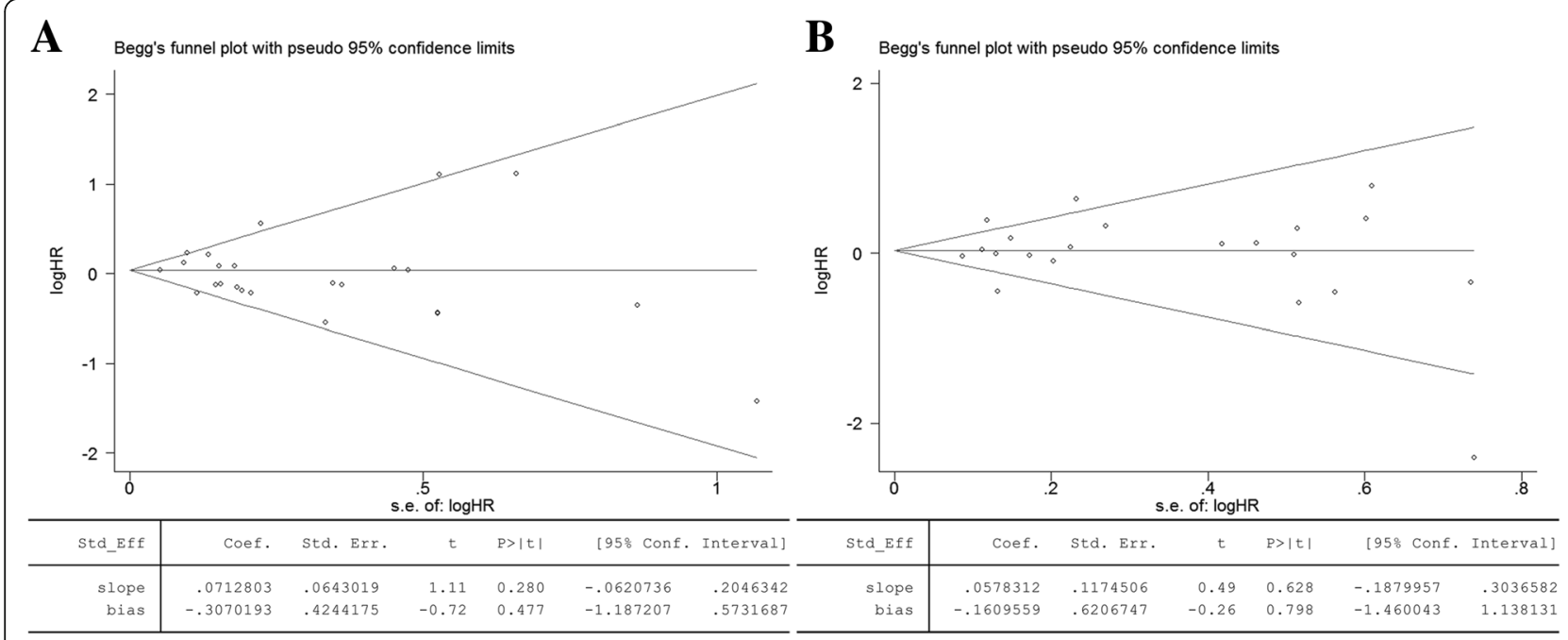

Fig. 8 Begg's and Egger's tests for comparisons of PFS (a) and OS (b) 
erlotinib can significantly improve PFS as compared to gemcitabine+cisplatin in patients with EGFR mutationpositive NSCLC [59]. Another phase III RCT suggested that PFS is significantly longer with gefitinib treatment in patients with mutation-positive NSCLC as compared with carboplatin+paclitaxel [60]. Several other high-quality RCTs have reported similar results [61-63]. Based on these positive results, the US Food and Drug Administration approved gefitinib as first-line treatment for EGFR mutation-positive NSCLC [64]. In the 2017 National Comprehensive Cancer Network (NCCN) guideline on NSCLC, both gefitinib and erlotinib are suggested as first-line treatment for EGFR mutation-positive NSCLC [65].

Several limitations should considered when interpreting our results. First, only high-quality studies published in English were included, which might result in language bias. Second, only three RCTs were included, which would weaken the quality of the results. Third, there was significant heterogeneity for some comparisons (OS and total/grade 3-5 AEs), which would weaken the reliability of these results. Fourth, the type and rate of EGFR mutations differed between the included studies, which might increase heterogeneity and weaken the quality of the results. Fifth, we obtained data from only three East Asian countries (China [Mainland and Taiwan], Japan, Korea), which might reduce the representativeness of the study. Sixth, quality of life and survival time are two equally important evaluating indicators for a treatment. Quality of life cannot simply be replaced by the number of AEs. However, the included studies did not compare quality of life between treatment with the two EGFR TKIs. Accordingly, we suggest that quality of life be considered an essential indicator in future drug evaluation studies.

\section{Conclusion}

Our results show that both gefitinib and erlotinib are effective for treating advanced NSCLC in East Asian patients, with comparable PFS, OS, ORR, and DCR. Erlotinib induces a significantly higher rate and severity of skin rash, nausea/vomiting, fatigue, and stomatitis, which might cause a higher rate of dose reduction. Therefore, we suggest that individualized drug dose based on weight or body surface area might be more appropriate than a fixed oral dose for both agents in treating East Asian patients with advanced NSCLC. However, due to the inherent limitations of our meta-analysis, more large-scale, high-quality RCTs are warranted to confirm this conclusion.

\section{Additional files}

Additional file 1: Figure S1. Cumulative meta-analysis related to PFS associated with gefitinib versus erlotinib. (TIFF $1895 \mathrm{~kb}$ )
Additional file 2: Figure S2. Cumulative meta-analysis related to OS associated with gefitinib versus erlotinib. (TIFF $1885 \mathrm{~kb}$ )

Additional file 3: Figure S3. Cumulative meta-analysis related to ORR associated with gefitinib versus erlotinib. (TIFF $1498 \mathrm{~kb}$ )

Additional file 4: Figure S4. Cumulative meta-analysis related to DCR associated with gefitinib versus erlotinib. (TIF $1379 \mathrm{~kb}$ )

Additional file $\mathbf{5}$ Figure $\mathbf{S 5}$. Cumulative meta-analysis related to total AEs associated with gefitinib versus erlotinib. (TIFF $999 \mathrm{~kb}$ )

Additional file 6: Figure $\mathbf{5 6}$. Cumulative meta-analysis related to grade 3-5 AEs associated with gefitinib versus erlotinib. (TIFF $1104 \mathrm{~kb}$ )

\section{Abbreviations}

AEs: Adverse effects; ASR: Age-standardized rate; Cl: Confidence interval; DCR: Disease control rate; EGFR TKIs: Epidermal growth factor receptor tyrosine kinase inhibitors; HR: Hazard ratios; NOS: Newcastle-Ottawa Scale; NSCLC: Non-small cell lung cancer; ORR: Objective response rate; OS: Overall survival; PFS: Progression-free survival; PRISMA: Preferred Reporting Items for Systematic Review and Meta-Analysis; RR: Risk ratios

\section{Acknowledgements}

The authors would like to thank Dr. Han Jiang for the data collection, Professor Yanhua Tang for her advice and assistance in language improvement, and all the patients who participated in this study.

\section{Funding}

This study was supported by National Natural Science Foundation of China (NSFC), with no commercial entity involved, number of grants (81560345). Role of the Funding: The NSFC had no role in the design and conduct of the study; collection, management, analysis, and interpretation of the data; preparation, review, or approval of the manuscript; and decision to submit the manuscript for publication.

\section{Availability of data and materials}

All data is available in this paper.

\section{Authors' contributions}

WXZ conceived of the idea, designed the study, searched the relevant database and wrote the manuscript. DLY interpreted the data and performed the study through STATA. JHP interpreted the data and other relevant information. JJX analyzed quality of each study and confirmed statistical analyses. YW provided the examination for the methodology, reviewed and revised our manuscript. All authors read and approved the final manuscript.

Ethics approval and consent to participate

Not applicable.

\section{Consent for publication}

Not applicable.

\section{Competing interests}

The authors declare that they have no competing interests.

\section{Publisher's Note}

Springer Nature remains neutral with regard to jurisdictional claims in published maps and institutional affiliations.

Received: 17 April 2018 Accepted: 22 July 2018

Published online: 02 August 2018

References

1. Siegel RL, Miller KD, Jemal A. Cancer statistics, 2018. CA Cancer J Clin. 2018; 68(1):7-30.

2. Chen W, Zheng R, Baade PD, Zhang S, Zeng H, Bray F, et al. Cancer statistics in China, 2015. CA Cancer J Clin. 2016;66(2):115-32.

3. Liu TC, Jin $X$, Wang $Y$, Wang K. Role of epidermal growth factor receptor in lung cancer and targeted therapies. Am J Cancer Res. 2017;7(2):187-202. 
4. Malik PS, Jain D, Kumar L. Epidermal growth factor receptor tyrosine kinase inhibitors in advanced non-small cell lung cancer. Oncology. 2016;91(1):26-34.

5. NICE, EGFR-TK mutation testing in adults with locally advanced or metastatic non-small-cell lung cancer. http://www.nice.org.uk/guidance/dg9, (Accessed 2 Aug 2016).

6. National Comprehensive Cancer Network Practice guidelines in oncologyversion V.4.2016 (non-small-cell lung cancer). https://www.nccn.org/ professionals/physician_gls/pdf/nscl.pdf. Accessed 2 Aug 2016.

7. Dearden S, Stevens J, Wu YL, Blowers D. Mutation incidence and coincidence in non small-cell lung cancer: meta-analyses by ethnicity and histology (mutMap). Ann Oncol. 2013;24(9):2371-6.

8. Wu YL, Saijo N, Thongprasert S, Yang JC, Han B, Margono B, et al. Efficacy according to blind independent central review: post-hoc analyses from the phase III, randomized, multicenter, IPASS study of first-line gefitinib versus carboplatin/paclitaxel in Asian patients with EGFR mutation-positive advanced NSCLC. Lung Cancer. 2017;104:119-25.

9. Chang GC, Tsai CM, Chen KC, Yu CJ, Shih JY, Yang TY, et al. Predictive factors of gefitinib antitumor activity in east Asian advanced non-small cell lung cancer patients. J Thorac Oncol. 2006;1(6):520-5.

10. Urata Y, Katakami N, Morita S, Kaji R, Yoshioka H, Seto T, et al. Randomized phase III study comparing gefitinib with erlotinib in patients with previously treated advanced lung adenocarcinoma: WJOG 5108L. J Clin Oncol. 2016;34(27):3248-57

11. Yang JJ, Zhou Q, Yan HH, Zhang XC, Chen HJ, Tu HY, et al. A phase III randomised controlled trial of erlotinib vs gefitinib in advanced non-small cell lung cancer with EGFR mutations. Br J Cancer. 2017;116(5):568-74.

12. Shin HJ, Kim TO, Kang HW, Chi SY, Ban HJ, Kim SO, et al. Comparison of therapeutic efficacy of gefitinib and erlotinib in patients with squamous cell lung cancer. Tuberculosis \& Respiratory Diseases. 2011;71(1):15-23.

13. Sato S, Kurishima K, Miyazaki K, Kodama T, Ishikawa H, Kagohashi K, et al. Efficacy of tyrosine kinase inhibitors in non-small-cell lung cancer patients undergoing dose reduction and those with a low body surface area. Mol Clin Oncol. 2014;2(4):604-8

14. Fan WC, Yu CJ, Tsai CM, Huang MS, Lai CL, Hsia TC, et al. Different efficacies of erlotinib and gefitinib in taiwanese patients with advanced non-small cell lung cancer: a retrospective multicenter study. J Thorac Oncol. 2011;6(1): 148-55.

15. Kuan FC, Li SH, Wang CL, Lin MH, Tsai YH, Yang CT. Analysis of progressionfree survival of first-line tyrosine kinase inhibitors in patients with non-small cell lung cancer harboring leu858Arg or exon 19 deletions. Oncotarget. 2017;8(1):1343-53.

16. Jadad AR, Moore RA, Carroll D, Jenkinson C, Reynolds DJ, Gavaghan DJ, et al. Assessing the quality of reports of randomized clinical trials: is blinding necessary? Control Clin Trials. 1996;17(1):1-12.

17. Wells GA, Shea BJ, O'Connell D, Peterson J, Welch V, Losos M, et al. The Newcastle-Ottawa scale (nos) for assessing the quality of non-randomized studies in meta-analysis. Appl Eng Agric. 2014;18(6):727-34.

18. Tierney JF, Stewart LA, Ghersi D, Burdett S, Sydes MR. Practical methods for incorporating summary time-to-event data into meta-analysis. Trials. 2007;8:16.

19. Kim ST, Lee J, Kim JH, Won YW, Sun JM, Yun J, et al. Comparison of gefitinib versus erlotinib in patients with non-small cell lung cancer who failed previous chemotherapy. Cancer. 2010;116(12):3025-33.

20. Hotta K, Kiura K, Takigawa N, Yoshioka H, Harita S, Kuyama S, et al. Comparison of the incidence and pattern of interstitial lung disease during erlotinib and gefitinib treatment in Japanese patients with non-small cell lung cancer: the Okayama lung Cancer study group experience. J Thorac Oncol. 2010;5(2):179-84.

21. Hong J, Kyung SY, Lee SP, Park JW, Jung SH, Lee Jl, et al. Pemetrexed versus gefitinib versus erlotinib in previously treated patients with non-small cell lung cancer. Korean J Intern Med. 2010;25(3):294-300.

22. Wu JY, Wu SG, Yang CH, Chang YL, Chang YC, Hsu YC, et al. Comparison of gefitinib and erlotinib in advanced NSCLC and the effect of EGFR mutations. Lung Cancer. 2011;72(2):205-12.

23. Togashi Y, Masago K, Fujita S, Hatachi Y, Fukuhara A, Nagai H, et al. Differences in adverse events between $250 \mathrm{mg}$ daily gefitinib and $150 \mathrm{mg}$ daily erlotinib in Japanese patients with non-small cell lung cancer. Lung Cancer. 2011;74(1):98-102.

24. Jung M, Kim SH, Lee YJ, Hong S, Kang YA, Kim SK, et al. Prognostic and predictive value of CEA and CYFRA 21-1 levels in advanced non-small cell lung cancer patients treated with gefitinib or erlotinib. Exp Ther Med. 2011;2(4):685.
25. Wu WS, Chen YM, Tsai CM, Shih JF, Chiu CH, Chou KT, et al. Erlotinib has better efficacy than gefitinib in adenocarcinoma patients without EGFRactivating mutations, but similar efficacy in patients with EGFR-activating mutations. Exp Ther Med. 2012;3(2):207-13.

26. Kim ST, Uhm JE, Lee J, Sun JM, Sohn I, Kim SW, et al. Randomized phase II study of gefitinib versus erlotinib in patients with advanced non-small cell lung cancer who failed previous chemotherapy. Lung Cancer. 2012;75(1):82-8

27. Suzumura T, Kimura T, Kudoh S, Umekawa K, Nagata M, Matsuura K, et al. Reduced CYP2D6 function is associated with gefitinib-induced rash in patients with non-small cell lung cancer. BMC Cancer. 2012;12:568.

28. Yoshida T, Yamada K, Azuma K, Kawahara A, Abe H, Hattori S, et al. Comparison of adverse events and efficacy between gefitinib and erlotinib in patients with non-small-cell lung cancer: a retrospective analysis. Med Oncol. 2013;30(1):349.

29. Shao YY, Shau WY, Lin ZZ, Chen HM, Kuo R, Yang JC, et al. Comparison of gefitinib and erlotinib efficacies as third-line therapy for advanced nonsmall-cell lung cancer. Eur J Cancer. 2013;49(1):106-14.

30. Lee E, Keam B, Kim DW, Kim TM, Lee SH, Chung DH, et al. Erlotinib versus gefitinib for control of leptomeningeal carcinomatosis in non-small-cell lung cancer. J Thorac Oncol. 2013;8(8):1069-74

31. Yu S, Wang Y, Li J, Hao X, Wang B, Wang Z, et al. Gefitinib versus erlotinib as salvage treatment for lung adenocarcinoma patients who benefited from the initial gefitinib: a retrospective study. Thoracic Cancer. 2013;4(2):109-16.

32. Lim SH, Lee JY, Sun JM, Ahn JS, Park K, Ahn MJ. Comparison of clinical outcomes following gefitinib and erlotinib treatment in non-small-cell lung cancer patients harboring an epidermal growth factor receptor mutation in either exon 19 or 21. J Thorac Oncol. 2014;9(4):506-11.

33. Lin GN, Peng JW, Liu PP, Liu DY, Xiao JJ, Chen XQ. Elevated neutrophil-tolymphocyte ratio predicts poor outcome in patients with advanced nonsmall-cell lung cancer receiving first-line gefitinib or erlotinib treatment. Asia Pac J Clin Oncol. 2014;110(7):2696-703.

34. Ren S, Su C, Wang Z, Li J, Fan L, Li B, et al. Epithelial phenotype as a predictive marker for response to EGFR-TKls in non-small cell lung cancer patients with wild-type EGFR. Int J Cancer. 2014;135(12):2962-71.

35. Li J, Li X, Ren S, Chen X, Zhang Y, Zhou F, et al. miR-200c overexpression is associated with better efficacy of EGFR-TKls in non-small cell lung cancer patients with EGFR wild-type. Oncotarget. 2014;5(17):7902-16.

36. Takeda M, Okamoto I, Nakagawa K. Survival outcome assessed according to tumor response and shrinkage pattern in patients with EGFR mutation-positive non-small cell lung cancer treated with geftinib or erlotinib. J Thorac Oncol. 2014;9(2):200-4.

37. Otsuka T, Mori M, Yano Y, Uchida J, Nishino K, Kaji R, et al. Effectiveness of tyrosine kinase inhibitors in Japanese patients with non-small cell lung cancer harboring minor epidermal growth factor receptor mutations: results from a multicenter retrospective study (HANSHIN oncology group 0212). Anticancer Res. 2015;35(7):3885-91.

38. Song Z, Zhang Y. Efficacy of gefitinib or erlotinib in patients with squamous cell lung cancer. Arch Med Sci. 2015;11(1):164-8.

39. Koo DH, Kim KP, Choi CM, Lee DH, Lee JC, Lee JS, et al. EGFR-TKI is effective regardless of treatment timing in pulmonary adenocarcinoma with EGFR mutation. Cancer Chemother Pharmacol. 2015;75(1):197-206.

40. Ruan Y, Jiang J, Guo L, Li Y, Huang H, Shen L, et al. Genetic association of curative and adverse reactions to tyrosine kinase inhibitors in Chinese advanced non-small sell lung cancer patients. Sci Rep. 2016;6:23368.

41. Hirano R, Uchino J, Ueno M, Fujita M, Watanabe K. Low-dose epidermal growth factor receptor (EGFR)-tyrosine kinase inhibition of EGFR mutationpositive lung cancer: therapeutic benefits and associations between dosage efficacy and body surface area. Asian Pac J Cancer Prev. 2016;17(2):785-9.

42. Suh KJ, Keam B, Kim M, Park YS, Kim TM, Jeon YK, et al. Serum neuron-specific enolase levels predict the efficacy of first-line epidermal growth factor receptor (EGFR) tyrosine kinase inhibitors in patients with non-small cell lung cancer harboring EGFR mutations. Clin Lung Cancer. 2016;17(4):245-52.

43. Kashima J, Okuma Y, Miwa M, Hosomi Y. Survival of patients with brain metastases from non-small cell lung cancer harboring EGFR mutations treated with epidermal growth factor receptor tyrosine kinase inhibitors. Med Oncol. 2016;33(11):129.

44. Yun $\mathrm{CH}$, Boggon TJ, Li Y, Woo MS, Greulich $\mathrm{H}$, Meyerson M, et al. Structures of lung cancer-derived EGFR mutants and inhibitor complexes: mechanism of activation and insights into differential inhibitor sensitivity. Cancer Cell. 2007;11(3):217-27. 
45. Ling J, Fettner S, Lum BL, Riek M, Rakhit A. Effect of food on the pharmacokinetics of erlotinib, an orally active epidermal growth factor receptor tyrosine-kinase inhibitor, in healthy individuals. Anti-Cancer Drugs. 2008;19(2):209-16.

46. Cantarini MV, McFarquhar T, Smith RP, Bailey C, Marshall AL. Relative bioavailability and safety profile of gefitinib administered as a tablet or as a dispersion preparation via drink or nasogastric tube: results of a randomized, open-label, three-period crossover study in healthy volunteers. Clin Ther. 2004:26(10):1630-6.

47. Russo A, Franchina T, Ricciardi GR, Picone A, Ferraro G, Zanghì M, et al. A decade of EGFR inhibition in EGFR-mutated non small cell lung cancer (NSCLC): old successes and future perspectives. Oncotarget. 2015;6(29): 26814-25

48. Yang SC, Lai WW, Hsiue TR, Su WC, Lin CK, Hwang JS, et al. Healthrelated quality of life after first-line anti-cancer treatments for advanced non-small cell lung cancer in clinical practice. Qual Life Res. 2016;25(6):1441-9.

49. Wu YL, Fukuoka M, Mok TS, Saijo N, Thongprasert S, Yang JC, et al. Tumor response and health-related quality of life in clinically selected patients from Asia with advanced non-small-cell lung cancer treated with first-line gefitinib: post hoc analyses from the IPASS study. Lung Cancer. 2013;81(2):280-7.

50. Baselga J, Rischin D, Ranson M, Calvert H, Raymond E, Kieback DG, et al. Phase I safety, pharmacokinetic, and pharmacodynamic trial of ZD1839, a selective oral epidermal growth factor receptor tyrosine kinase inhibitor, in patients with five selected solid tumor types. J Clin Oncol. 2002;20(21): 4292-302.

51. Hidalgo M, Siu LL, Nemunaitis J, Rizzo J, Hammond LA, Takimoto C, et al. Phase I and pharmacologic study of OSI-774, an epidermal growth factor receptor tyrosine kinase inhibitor, in patients with advanced solid malignancies. J Clin Oncol. 2001;19(13):3267-79.

52. Rukazenkov Y, Speake G, Marshall G, Anderton J, Davies BR, Wilkinson RW et al. Epidermal growth factor receptor tyrosine kinase inhibitors: similar but different? Anti-Cancer Drugs. 2009;20(10):856-66.

53. Mok T, Wu YL, Au JS, Zhou C, Zhang L, Perng RP, Park K. Efficacy and safety of erlotinib in 1242 east/south-east Asian patients with advanced non-small cell lung cancer. J Thorac Oncol. 2010;5(10):1609-15.

54. Ando M, Okamoto I, Yamamoto N, Takeda K, Tamura K, Seto T, et al. Predictive factors for interstitial lung disease, antitumor response, and survival in non-small-cell lung cancer patients treated with gefitinib. J Clin Oncol. 2006:24(16):2549-56.

55. Yeo WL, Riely GJ, Yeap BY, Lau MW, Warner JL, Bodio K, et al. Erlotinib at a dose of 25 mg daily for non-small cell lung cancers with EGFR mutations. J Thorac Oncol. 2010;5(7):1048-53.

56. Takashima N, Kimura T, Watanabe N, Umemura T, Katsuno S, Arakawa K, et al. Prognosis in patients with non-small cell lung cancer who received erlotinib treatment and subsequent dose reduction due to skin rash. Onkologie. 2012;35(12):747-52.

57. Satoh $H$, Inoue A, Kobayashi K, Maemondo M, Oizumi S, Isobe H, et al. Lowdose gefitinib treatment for patients with advanced non-small cell lung cancer harboring sensitive epidermal growth factor receptor mutations. J Thorac Oncol. 2011;6(8):1413-7

58. Sim SH, Keam B, Kim DW, Kim TM, Lee SH, Chung DH, et al. The gefitinib dose reduction on survival outcomes in epidermal growth factor receptor mutant non-small cell lung cancer. J Cancer Res Clin Oncol. 2014;140(12): 2135-42.

59. Wu YL, Zhou C, Liam CK, Wu G, Liu X, Zhong Z, et al. First-line erlotinib versus gemcitabine/cisplatin in patients with advanced EGFR mutationpositive non-small-cell lung cancer: analyses from the phase III, randomized, open-label. ENSURE study Ann Oncol. 2015;26(9):1883-9.

60. Fukuoka M, Wu YL, Thongprasert S, Sunpaweravong P, Leong SS, Sriuranpong $V$, et al. Biomarker analyses and final overall survival results from a phase III, randomized, open-label, first-line study of gefitinib versus carboplatin/paclitaxel in clinically selected patients with advanced non-small-cell lung cancer in Asia (IPASS). J Clin Oncol. 2011;29(21):2866-74.

61. Fiala O, Pesek M, Finek J, Benesova L, Bortlicek Z, Minarik M. Comparison of EGFR-TKI and chemotherapy in the first-line treatment of advanced EGFR mutation-positive NSCLC. Neoplasma. 2013;60(4):425-31.
62. Zhou C, Wu YL, Chen G, Feng J, Liu XQ, Wang C, et al. Erlotinib versus chemotherapy as first-line treatment for patients with advanced EGFR mutation-positive non-small-cell lung cancer (OPTIMAL, CTONG-0802): a multicentre, open-label, randomised, phase 3 study. Lancet Oncol. 2011;12(8):735-42

63. Rosell R, Carcereny E, Gervais R, Vergnenegre A, Massuti B, Felip E, et al. Erlotinib versus standard chemotherapy as first-line treatment for European patients with advanced EGFR mutation-positive non-small-cell lung cancer (EURTAC): a multicentre, open-label, randomised phase 3 trial. Lancet Oncol. 2012;13(3):239-46.

64. Kazandjian D, Blumenthal GM, Yuan W, He K, Keegan P, Pazdur R. FDA approval of gefitinib for the treatment of patients with metastatic EGFR mutation-positive non-small cell lung cancer. Clin Cancer Res. 2016;22(6):1307-12.

65. National Comprehensive Cancer Network. (NCCN) Clinical Practice Guidelines in Oncology. Small Cell Lung Cancer (Version 5. 2017). Available at https://www.nccn.org/professionals/physician_gls/pdf/sclc.pdf. Accessed 16 Mar 2017.
Ready to submit your research? Choose BMC and benefit from:

- fast, convenient online submission

- thorough peer review by experienced researchers in your field

- rapid publication on acceptance

- support for research data, including large and complex data types

- gold Open Access which fosters wider collaboration and increased citations

- maximum visibility for your research: over $100 \mathrm{M}$ website views per year

At BMC, research is always in progress.

Learn more biomedcentral.com/submissions 